DOI

\title{
ОСОБЛИВОСТІ ЯКОСТІ ЖИТТЯ ЕМІГРАНТІВ ТА РЕЕМІГРАНТІВ, ХВОРИХ НА ДЕПРЕСИВНІ РОЗЛАДИ
}

๑о. П. Венгер

\section{ДВНЗ «Тернопільський державний медичний університет імені І. Я. Горбачевського мОз України»}

РЕЗЮМЕ. Проведене дослідження особливостей якості життя у 196 емігрантів, 191 реемігранта у порівнянні з 198 не емігрантами, хворими на різні форми депресивних розладів, за допомогою шкали якості життя ВООЗ яж-26 виявило низький рівень якості життя у емігрантів та реемігрантів, хворих на депресивні розлади, особливо у сферах психологічної якості життя, соціальної якості життя та фізичного здоров'я. Найгірші показники у сфері психологічної та соціальної якості життя виявлені у реемігрантів, що може бути пов'язано із впливом стресу реадаптації. У емігрантів показники якості життя, за винятком сфери оточення, також є гіршими, ніж у не емігрантів. Вплив фактора еміграції та рееміграції максимально виражений у хворих на психогенні депресивні розлади і виявляється менше за наявності ендогенного та органічного депресивного розладу.

КЛЮчОВІ СлОВА: емігранти, реемігранти, депресивні розлади, якість життя.

Вступ. Однією з найактуальніших суспільних та державних проблем в Україні $\epsilon$ проблема еміграції та рееміграції. Значущість її зумовлена значною кількістю українських емігрантів (близько 6,5-7 млн чол. а6о 15 \% постійного населення), яка, до того $ж$, має постійну тенденцію до збільшення $[1,2]$.

3 сучасних наукових позицій еміграція розглядається як фактор, що здатен спровокувати маніфестацію або екзацербацію ендогенних психічних захворювань, а також призвести до особистісної трансформації з посиленням таких несприятливих характеристик як емоційна нестійкість, тривожність, соціальна інтроверсія, конформність, підозріливість, слабка інтеграція особистісних рис у вигляді емотивності та фрустрованості, низький рівень фрустраційної толерантності [3-5].

Останніми роками набуває усе більшого наукового і практичного значення дослідження якості життя (ЯЖ), яку розглядають як актуальний методологічний підхід в психіатрії, що характеризує соціально-психологічний і фізичний рівні адаптації пацієнта, а також стан розвитку суспільства, держави, регіону [6-9]. При цьому актуальні питання ЯЖ емігрантів та реемігрантів, хворих на депресивні розлади різного ґенезу, $\epsilon$ практично недослідженими.

Метою дослідження було вивчення особливостей якості життя у емігрантів та реемігрантів, хворих на депресивні розлади.

Відповідно до мети дослідження нами було обстежено 196 осіб, які щонайменше протягом останнього року проживали за межами України і планували найближчим часом повернутися за кордон (емігранти), 191 особа, яка не менше року проживала за межами України і протягом останнього року повернулася для постійного проживання в Україну (реемігранти) та 198 осіб, які постійно проживають в Україні і ніколи не ви- їжджали за їі межі для тривалого проживання (не емігранти). Усі обстежені хворі перебували на лікуванні у Тернопільській обласній психоневрологічній лікарні за період 2010 - 2014 років, їм був встановлений остаточний клінічний діагноз депресивного розладу відповідно до критеріїв MKX-10. Психогенні депресивні розлади (коди за MKX-10 F43.21 та F43.22) встановлені у 69 не емігрантів, 68 емігрантів та 67 реемігрантів, ендогенні (коди за MKX-10 F31.3, F31.4, F32.1, F32.2, F33.1 та F33.2) - відповідно у 65, 66 та 63 осіб, органічні (код за MKX-10 F06.3) - відповідно у 64, 62 та 61 особи. Обстеження проведено за допомогою шкали якості життя ВООЗ ЯЖ-26 [10].

Статистичний аналіз результатів проводили за допомогою непараметричних методів: тесту Манна-Уїтні, критерію хі-квадрат Пірсона та точного критерію Фішера.

При вивченні загальної самооцінки ЯЖ хворими на психогенні депресивні розлади було виявлено, що найгірше оцінюють власну Яж реемігранти. Дуже погано оцінюють власну Яж $43,2 \%$ реемігрантів, $36,8 \%$ емігрантів та $24,7 \%$ не емігрантів, погано - відповідно 26,9 \%, 25,0 \% та $31,9 \%$, нейтрально оцінюють свою ЯЖ $27,5 \%$ не емігрантів, 13,2 \% емігрантів та 22,4 \% реемігрантів. Позитивна самооцінка ЯЖ частіше виявлялася у емігрантів: добре власну ЯЖ оцінюють $14,7 \%$ емігрантів, 13,0\% не емігрантів і лише 7,5\% реемігрантів, дуже добре - 10,3 \% емігрантів, 2,9 \% не емігрантів, щодо реемігрантів, то жоден з них не оцінив власну яЖ як дуже добру.

Хворим на ендогенні депресивні розлади притаманна гірша самооцінка власної ЯЖ. Як дуже погану оцінили ії 53,8 \% не емігрантів, 43,9 \% емігрантів та 61,9\% реемігрантів, як погану - відповідно $27,7 \%, 36,4 \%$ та 23,8 \%, як нейтральну $16,9 \%, 19,7 \%$ та 12,7 \%. Ендогенні депресії відрізняються тяжким перебігом, тож закономірною $\epsilon$ 
Огляди літератури, оригінальні дослідження, погляд на проблему

відсутність серед обстежених осіб, які 6 оцінили власну яЖ як дуже добру. Таким чином, закономірності, виявлені у хворих на психогенні депресії щодо найгіршої самооцінки ЯЖ реемігрантами, зберігаються і у хворих на ендогенні депресивні розлади, однак вплив тяжкого ендогенного захворювання певною мірою нівелює відмінності, пов'язані з еміграцією та рееміграцією.

Серед хворих на органічні депресивні розлади також домінують негативні оцінки власної Яж. Так, дуже погано оцінюють власну якість життя $43,7 \%$ не емігрантів, 51,7 \% емігрантів та $60,7 \%$ реемігрантів, погано - відповідно 34,4 \%, 27,4 \% та 31,1 \%, нейтрально - 12,5\%, 16,1 \% та 8,2 \%. Добрі оцінки власної Яж у цій групі, на відміну від групи психогенних депресій, частіше зустрічаються у не емігрантів (7,8\%), ніж у емігрантів (3,2\%); у цих двох групах також виявлено одиничні оцінки власної яЖ як дуже доброї. Серед реемігрантів, хворих на органічні депресивні розлади, добра та дуже добра самооцінка ЯЖ не виявлена.

Схожа ситуація виявлена при самооцінці задоволеності станом власного здоров'я. У групі хворих на психогенні депресивні розлади найнижчі оцінки виявлені у реемігрантів: дуже не задоволені власним станом здоров'я 40,2 \% реемігрантів, 30,9\% емігрантів та 24,7\% не емігрантів, не задоволені - 28,4 \% реемігрантів, 39,7 \% емігрантів, нейтрально оцінюють його відповідно 26,1\%, $16,2 \%$ та 25,4 \% хворих. Задоволені власним станом здоров'я 10,1\% не емігрантів, 10,3 \% емігрантів та 6,0\% реемігрантів. Серед не емігрантів та емігрантів виявлені одиничні випадки дуже високої самооцінки власного здоров'я.

У групі хворих на ендогенні депресії переважна більшість обстежених оцінюють власне здоров'я негативно: 53,8 \% не емігрантів, 45,6 \% емігрантів та $61,9 \%$ реемігрантів дуже не задоволені ним, 18,5 \% не емігрантів, 24,2 \% емігрантів та 22,2 \% реемігрантів - не задоволені. Нейтрально оцінюють власне здоров'я 23,1 \% не емігрантів, 24,2 \% емігрантів та 14,3 \% реемігрантів, задовільно - 3,1 \% не емігрантів, 3,0 \% емігрантів і 1,6 \% реемігрантів, 1 не емігрант та 2 емігранти оцінили свій стан здоров'я дуже високо (відповідно $1,5 \%$ і $3,0 \%)$.

Серед хворих на органічні депресивні розлади виявлена схожа картина, хоча питома частка вкрай незадоволених власним здоров'ям серед емігрантів $\epsilon$ більшою, ніж серед не емігрантів, хоча й меншою, ніж у реемігрантів (відповідно $51,7 \%, 43,7 \%$ та 60,7 \%). Незадоволені власним станом здоров'я 34,4 \% не емігрантів, 27,4 \% емігрантів та 31,1\% реемігрантів, нейтрально оцінюють його 12,5 \% не емігрантів, 16,1 \% емігрантів та 8,2 \% реемігрантів, задовільно - 7,8 \% не емі- грантів та 3,2 \%, по 1 хворому серед не емігрантів та емігрантів оцінили свій стан здоров'я як дуже задовільний (по 1,6 \%).

При аналізі кількісних значень за окремими сферами ЯЖ емігрантів та реемігрантів були виявлені значущі відмінності, зумовлені впливом фактора еміграції.

Так, середнє значення показника ЯЖ за сферою фізичного здоров'я в групі не емігрантів, хворих на психогенні депресивні розлади, виявилося найвищим: $(41,8 \pm 9,4)$ балів, у групі емігрантів дещо нижчим - $(40,8 \pm 9,5)$ балів, і у групі реемігрантів - найнижчим: $(40,0 \pm 10,9)$ балів, при цьому розбіжності між групами статистично незначущі. Привертає увагу, що рівень ЯЖ за сферою фізичного здоров'я у обстежених хворих $\epsilon$ вельми низьким, його можна порівняти з характеристиками яЖ, виявленими у хворих на тяжкі хронічні соматичні захворювання.

Суттєво більші відмінності між показниками яж різних груп з урахуванням фактора еміграції виявлені у сфері психологічної ЯЖ. Так, у не емігрантів, хворих на психогенні депресивні розлади, середній показник у сфері психологічної ЯЖ склав $(32,8 \pm 13,3)$ балів, у емігрантів - $(30,8 \pm 15,2)$ балів, у реемігрантів - $(24,7 \pm 11,1)$ балів. Розбіжності за цим показником $\epsilon$ статистично значущими при порівнянні груп не емігрантів та реемігрантів $(p<0,01)$ і емігрантів та реемігрантів $(p<0,05)$. Таким чином, реемігранти виявили значуще нижчу ЯЖ у психологічній сфері, що узгоджується 3 виявленими нами особливостями змін у психоемоційній сфері, зокрема, більшою виразністю депресивних та астено-депресивних проявів у цій групі. Емігранти також виявляють нижчу яж у психологічній сфері, порівняно з не емігрантами, однак їх показники більшою мірою наближені до показників не емігрантів, ніж реемігрантів. Ці особливості також узгоджуються з даними клінічного та психодіагностичного обстеження: у емігрантів рівень виразності депресивних розладів $\epsilon$ меншим, ніж у реемігрантів, однак наявні прояви тривожно-депресивних розладів; крім того, емігранти мають кращі соціально-економічні перспективи, що також відображається на показниках психологічної Яж. Водночас слід зауважити, що в цілому показники за сферою психологічної ЯЖ у досліджених хворих є низькими, що закономірно з урахуванням наявності депресивного розладу.

У сфері соціальної ЯЖ також виявлені важливі закономірності. В цілому емігранти виявили суттєво нижчий рівень ЯЖ у цій сфері: $(38,1 \pm 16,7)$ балів, розбіжності значущі при порівнянні з групами не емігрантів $(p<0,01)$ та реемігрантів $(p<0,05)$. Очевидно, що низький рівень ЯЖ у сфері соціаль- 
Огляди літератури, оригінальні дослідження, погляд на проблему

ного життя зумовлений тривалим проживанням емігрантів у відриві від сім'ї, звичних соціальних зв'язків, у чужому мовному та культурному середовищі (до того ж, у більшості випадків, на положенні безправного нелегала). У реемігрантів показник у сфері соціальної ЯЖ вищий, ніж у емігрантів, але нижчий, ніж у не емігрантів $(44,5 \pm 16,2)$ балів проти $(46,0 \pm 16,3)$ балів, розбіжності статистично не значущі. В цілому показники яж за цією сферою у всіх досліджених групах $\epsilon$ низькими.

Значущі розбіжності виявлені і за показниками ЯЖ у сфері оточення, однак у цій сфері показники емігрантів суттєво кращі, ніж у не емігрантів та реемігрантів, причому у емігрантів вони вищі за середній рівень: $(59,8 \pm 12,9)$ балів проти $(47,2 \pm 19,0)$ у не емігрантів та $(48,6 \pm 13,2)$ балів у реемігрантів. Розбіжності статистично значущі при порівнянні груп емігрантів з не емігрантами та реемігрантами $(p<0,01)$. Такі особливості $\epsilon$ цілком закономірними, адже рівень життя у країнах Євросоюзу є суттєво вищим, ніж в Україні; до того ж, емігранти мають суттєво краще матеріальне забезпечення, порівняно з не емігрантами та реемігрантами.

У хворих ендогенні депресивні розлади роблять значний відбиток на рівень Яж у всіх сферах, тому у цій групі відмінності, пов'язані із фактором еміграції, виражені меншою мірою. Так, середній показник ЯЖ у сфері фізичного здоров'я хворих на ендогенні депресії реемігрантів виявився найнижчим: $(39,4 \pm 9,3)$ балів, а у не емігрантів та емігрантів - практично однаковим: $(41,3 \pm 11,4)$ балів та $(41,7 \pm 11,4)$ балів відповідно, при цьому розбіжності статистично незначущі.

За сферою психологічної ЯЖ, як і в групі психогенних депресивних розладів, найнижчі показники виявлені у реемігрантів: $(17,8 \pm 7,2)$ балів проти $(21,9 \pm 11,7)$ балів у емігрантів та $(24,4 \pm 8,3)$ балів у не емігрантів; слід зауважити, що кількісні характеристики показників за сферою психологічної Яж у хворих на депресивні розлади ендогенного характеру є надзвичайно низькими. Значущі розбіжності виявлені при порівнянні груп не емігрантів та емігрантів $(p<0,1)$, не емігрантів та реемігрантів $(p<0,01)$, емігрантів та реемігрантів $(p<0,1)$.

За сферою соціальної ЯЖ обстежені хворі виявили низькі показники, при цьому найнижча ЯЖ була притаманна емігрантам; закономірності аналогічні тим, що виявлені у хворих на психогенні депресії. Так, середній показник ЯЖ за цією сферою у емігрантів склав $(37,7 \pm 14,6)$ балів, у реемігрантів $(41,9 \pm 12,7)$ балів, у не емігрантів - $(46,2 \pm 10,9)$ балів. Розбіжності $\epsilon$ статистично значущими при порівнянні груп не емігрантів та емігрантів $(p<0,01)$, не емігрантів та реемігрантів $(p<0,05)$.
За сферою оточення у хворих на ендогенні депресивні розлади найвищі показники виявлені у групі емігрантів $((53,0 \pm 12,7)$ балів), однак, вони $є$ нижчими, ніж у хворих на психогенні депресії. У не емігрантів рівень ЯЖ у сфері оточення виявився незначно нижчим, ніж у реемігрантів $((46,8 \pm 12,5)$ балів проти $(49,0 \pm 13,4)$ балів, розбіжності статистично незначущі).

Хворі на органічні депресивні розлади складають найтяжчу групу в плані виразності різноманітної психопатологічної симптоматики, тому закономірними є виявлені у них найнижчі показники ЯЖ за основними сферами.

Так, середній показник ЯЖ за сферою фізичного здоров'я у не емігрантів, хворих на органіч-

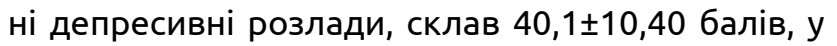
емігрантів - $(40,5 \pm 10,8)$ балів, у реемігрантів $(40,6 \pm 11,0)$ балів, розбіжності статистично незначущі. Очевидно, що основну роль у формуванні показників за цією шкалою відіграє основне захворювання, прояви якого нівелюють відмінності, зумовлені екзогенними факторами, у т.ч. фактором еміграції.

За сферою психологічної якості життя, як і у групах психогенної та ендогенної депресії, найнижчі показники виявлено у реемігрантів $(16,6 \pm 8,8)$ балів, більш високий рівень яЖ виявили емігранти - $(20,4 \pm 5,8)$ балів, і найвищий - не емігранти - $(24,1 \pm 12,9)$ балів. Слід зауважити, що показники за сферою психологічної ЯЖ у групі органічних депресивних розладів є найнижчими серед усіх груп, що є закономірним з урахуванням наявності тяжкої поєднаної психічної патології. Статистично значущі розбіжності за показниками яж у цій сфері виявлені при порівнянні груп не емігрантів та емігрантів $(p<0,1)$, не емігрантів та реемігрантів $(p<0,01)$, емігрантів та реемігрантів $(p<0,05)$.

За сферою соціальної якості життя у емігрантів та реемігрантів виявлені приблизно однакові низькі показники: $(34,7 \pm 16,7)$ балів та $(34,0 \pm 15,0)$ відповідно, розбіжності статистично незначущі. У не емігрантів середнє значення показника за сферою соціальної ЯЖ склало $(39,7 \pm 15,9)$ балів. На наш погляд, у групі органічних депресивних розладів самосприйняття хворим стану соціальної адаптації значною мірою визначається особливостями органічної патології психіки, при цьому вплив екзогенних факторів нівелюється; водночас, альтернативним поясненням може бути вельми низький рівень соціальної адаптації у групі реемігрантів, що наближає їх показники до притаманних емігрантам.

У сфері оточенняпоказникияЖхворихна органічні депресивні розлади тотожні тим, що виявлені у хворих на ендогенні депресії. Найкращою є ЯЖ у 
Огляди літератури, оригінальні дослідження, погляд на проблему

емігрантів $((53,6 \pm 13,1)$ балів), найгіршою - у реемігрантів $((44,4 \pm 11,5)$ балів), показники не емігрантів

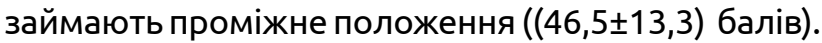
Статистично значущі розбіжності виявлені при порівнянні груп не емігрантів та емігрантів $(p<0,01)$, емігрантів та реемігрантів $(p<0,01)$.

Висновок. При аналізі особливостей яЖ емігрантів та реемігрантів, хворих на депресивні розлади, були виявлені важливі закономірності. Загальною тенденцією, зумовленою впливом депресії, $\epsilon$ низький рівень ЯЖ (особливо у сфері психологічної ЯЖ), а також фізичного здоров'я та соціальної ЯЖ. У реемігрантів психологічна ЯЖ та соціальна ЯЖ $є$ найнижчими серед усіх груп, а емігранти виявляють ознаки кращої ЯЖ у сфері оточення. За винятком сфери оточення, у емігрантів показники ЯЖ $\epsilon$ гіршими, ніж у не емігрантів, але кращими, ніж у реемігрантів. Вплив фактора еміграції (рееміграції) $\epsilon$ найбільшим у групі хворих на психогенні депресивні розлади і меншою мірою проявляється на тлі ендогенного та органічного депресивного розладу.

\section{ЛITEPATУPA}

1. Міграція в Україні: факти і цифри / Міжнародна організація з міграції. - К. : Представництво МОМ в Україні, 2011. - 7 с.

2. Щорічна Доповідь про стан дотримання та захисту прав і свобод людини в Україні Уповноваженого Верховної Ради України з прав людини: Постанова Верховної Ради України від 05.04.2011 року № 3194-VI // Голос України. - 2011. - № 35. - С. 23-29.

3. Lauber C. Patterns of Psychiatric Inpatient Care in Migrants: Results from Switzerland / C. Lauber, B. Lay, W. Rossler // Swiss Medical Weekly. - 2006. № 135. - P. 50-56.

4. Хармз В. А. Медико-психологические аспекты нарушения психической адаптации эмигрантов: дис. на соискание ученой степени канд. психол. наук: 19.00.04 / Вахид Аблахад Хармз; Санкт-Петербургский гос. университет. - СПб., 2000. - 186 с.

5. Иванова М. В. Психическое здоровье мигрантов (клинический, социально-психологический и реабилитационный аспекты): дис. на соискание ученой степени канд. мед. наук: 14.01.18 / Марина Владимировна Иванова; НИИ психического здоровья СО РАМН. - Томск, 2007. -205 c.

6. Демчева Н. К. Показатели качества жизни и социального функционирования как оценочные критерии психического состояния / Н. К. Демчева // Сибирский вестник психиатрии и наркологии. - 2006. - № 2 (40). - С. $112-113$.

7. Куприянова И. Е. Вопросы качества жизни в превентивной психиатрии / И. Е. Куприянова // Онтогенетические аспекты психического здоровья населения : тезисы докладов научно-практической конференции (Омск, 19 - 20 апреля 2010 г.). - Томск : Изд-во «Иван Федоров", 2010. - С. 124-128.

8. Панкратова Е. В. Комплексная методика оценки качества жизни региона / Е. В. Панкратова // Вестник Иркутского государственнорго экономического университета. - 2009. - № 1. - С. 1-7.

9. Katschnig H. Quality of Life in Mental Disorders / H. Katschnig, H. Freeman, N. Sartorius. - New York: MPress, 2005. - 368 p.

10. Краткий опросник Всемирной организации здравоохранения для оценки качества жизни (The World Health Organization Quality Of Life (WHOQOL) bref). - Женева : Всемирная организация здравоохранения. $-2004 .-6$ c.

\section{PECULIARITIES OF LIFE QUALITY OF EMIGRANTS AND RE-EMIGRANTS WITH DEPRESSIVE DISORDERS}

๑O. P. Venher

\section{Horbachevsky Ternopil State Medical University}

SUMMARY. The study features the quality of life in 196 immigrants, 191 re-emigrants compared with 198 not immigrants suffering from various forms of depressive disorders, using the scale of quality of life WHO QOL-26 showed low quality of life of emigrants and re-emigrants, patients with depressive disorders, especially in the field of psychological quality of life and social quality of life and physical health. The worst performance in the psychological and social quality of life found in the re-emigrants, which may be due to the impact of stress rehabilitation. In immigrants the quality of life, with the exception of areas surrounding were also worse than not immigrants. The impact of emigration and re-emigration factor was the most pronounced in patients with psychogenic depressive disorders and is less in the presence of endogenous and organic depressive disorders.

KEY WORDS: immigrants, re-emigrants, depressive disorders, quality of life. 